\title{
Influence of the soil sealing on the geoaccumulation index of heavy metals and various pollution factors
}

\author{
Przemysław Charzyński $^{1}$ - Andrzej Plak ${ }^{2}$ - Agnieszka Hanaka ${ }^{3}$ \\ Received: 23 August 2016/Accepted: 5 December 2016/Published online: 16 December 2016 \\ (C) The Author(s) 2016. This article is published with open access at Springerlink.com
}

\begin{abstract}
Soil sealing belongs to the most destructive and damaging processes to the soil environment. Soil sealing interrupts or greatly restricts the exchange of matter and energy between the biosphere, hydrosphere, and atmosphere and the soil environment. The aim of this study was to compare the content of heavy metals $(\mathrm{Cd}, \mathrm{Cr}, \mathrm{Cu}, \mathrm{Hg}, \mathrm{Fe}, \mathrm{Ni}, \mathrm{Pb}, \mathrm{Zn})$ of Ekranic Technosols by applying indicators such as geoaccumulation index $\left(I_{\text {geo }}\right)$, enrichment factor $(\mathrm{EF})$, and pollution load index (PLI), which allowed to determine quantitatively the impact of the soil sealing degree on the content of heavy metals and to distinguish natural from anthropogenic sources of origin of heavy metals. In general, 42 soils from different parts of the city of Torun (NW Poland) were sampled and divided into three groups according to the degree of soil sealing: completely sealed with asphalt or concrete (A), semipermeable (partially sealed with cobblestones and concrete paving slabs (B)), and reference (non-sealed) (C). The results indicate that the artificial sealing in urban areas slightly affects the content of heavy metals in soils. However, based on PLI, $I_{\text {geo, }}$ and EF, it was found that the sealing has influence on soil
\end{abstract}

Responsible editor: Zhihong Xu

Andrzej Plak

aplak@poczta.umcs.lublin.pl

1 Faculty of Earth Sciences, Department of Soil Science and Landscape Management, Nicolaus Copernicus University in Torun, Lwowska St. 1, 87-100 Torun, Poland

2 Faculty of Earth Sciences and Spatial Management, Department of Soil Science and Protection, Maria Curie-Skłodowska University, Kraśnicka Ave. 2cd, 20-718 Lublin, Poland

3 Faculty of Biology and Biotechnology, Department of Plant Physiology, Maria Curie-Skłodowska University, Akademicka St. 19, 20-033 Lublin, Poland properties and unsealed soil is the most exposed to the accumulation of pollutants.

Keywords Ekranic Technosols $\cdot$ Enrichment factor · Geochemical load index $\cdot$ Heavy metals $\cdot$ Pollution assessment $\cdot$ Pollution load index $\cdot$ Soil sealing $\cdot$ Urban soils

\section{Introduction}

Understanding the complexity of the functioning of soil systems and the interaction with human activity is particularly important in urban areas. Due to a continuous human existence and activities, these soils are very often truncated or buried under transported material, as well as highly compacted and contaminated. As a consequence, their hydrological characteristics, degree of compaction and disturbances, and relocations of material from original horizons are extremely different from those of natural soil types.

The concentration of heavy metals in soils, associated with litogenesis and pedogenesis, depends on the mineralogical composition of parent material and the direction and pace of the process of soil formation, which determines the distribution of trace elements in the soil profile (Luo et al. 2012a; Wong et al. 2006). Moreover, technogenic activity applies all of the abovementioned processes. The study of heavy metal deposition and accumulation is of increasing interest because of the awareness that heavy metals present in soil may have negative consequences on the human health and whole environment. Heavy metals may enter into aquatic ecosystems from anthropogenic sources, such as industrial waste water discharges, sewage waste water, fossil fuel combustion, and atmospheric deposition. Urban soils are changed as a result of activity of various processes, i.e., sealing, compaction, storage, and mixing (Plak et al. 2015; Wei et al. 2013). Sealing the soil belongs to the most 
destructive processes to the soil environment. In principle, it is an irreversible process, which is defined as the destruction of soil cover by partial or total application of the soil impermeable layer. Total sealing of the soil in urban areas is caused by concrete or asphalt (Siebielec et al. 2015). Soils can also be sealed with a semi-permeable surface, e.g., concrete paving, which allows partial penetration of air and water (Nestroy 2006) and allows saving the certain features of soil (Piotrowska-Długosz and Charzyński 2015). In the European Union, on average 51\% of artificial surfaces are sealed, but the composition varies considerably among Member States, depending on the dominant settlement structures and the intensity of the interpretation of artificial surfaces (Siebielec et al. 2015). In urban areas, as a direct result of human activity, the impact of industrial and municipal building, industry and communication, and artifacts deposited in soil, heavy metals are present in high concentrations (Charzyński et al. 2013; Madrid et al. 2004; Puskas and Farsang 2009; Xia et al. 2011).

In order to determine the degree of contamination of surface soil levels with heavy metals, their concentration is compared with the content of the local geochemical background, or by calculation of geoaccumulation index $\left(I_{\text {geo }}\right)$, enrichment factor (EF), or pollution load index (PLI) (Horckmans et al. 2005; Muller 1969; Tomlinson et al. 1980). The main factors influencing the distribution of heavy metals in the soil profile are the content of humus and iron and manganese oxides, as well as texture, soil $\mathrm{pH}$, and the rinsing processes, accompanied by the movement of water within the soil profile (Luo et al. 2012b; Madrid et al. 2008). Metals of anthropogenic origin are more mobile than those of pedogenic origin. In urban areas, the nature of the metals accumulation and their genesis in the soil is often ambiguous, and all the abovementioned processes, which are widely described in the literature, are distorted when the soil is sealed (Kabata-Pendias and Pendias 1999; Reimann et al. 2005; Sauerwein 2011; Siebielec et al. 2015).

The aim of this study was to compare the content of heavy metals ( $\mathrm{Cd}, \mathrm{Cr}, \mathrm{Cu}, \mathrm{Hg}, \mathrm{Ni}, \mathrm{Pb}, \mathrm{Zn})$ of Ekranic Technosols from Torun, Poland, and adjacent, non-sealed soils. We assumed that the soils sealed for 30 to 40 years affect the diversity of heavy metal content in two separate groups of the completely and partially sealed soils while compared with the non-sealed soil. Moreover, we assumed that the use of indicators such as $I_{\mathrm{geo}}$, EF, and PLI allows to determine quantitatively the impact of the soil sealing on the content of heavy metals.

The problem of uncontrolled propagation of the sealed surface in Poland, especially in the cities, is remotely explored, and the processes occurring in the sealed soils are not comprehensively studied. Moreover, few researchers in the world do their research on geochemical environment of the sealed soil, focusing primarily on the changes in the physical properties or biological activity (lithium) (Greinert 2015; Puskás and Farsang 2009; Zhao et al. 2012). The presented studies show the unique issues related to the impact of (completely or partially) sealed soil on disturbance of heavy metal circulation, which is of great importance in terms of quality of life and health of urban residents, the condition of the environment in cities, and the penetration of pollutants into groundwater. The research material gives extensive knowledge about the impact of the sealing process on soil geochemistry.

\section{Materials and methods}

\section{Description of the study area and soil sampling}

The study sites were located within the area of Torun $\left(18.609^{\circ} \mathrm{E}\right.$, $53.020^{\circ} \mathrm{N}$ ), the city in the North West Poland (Fig. 1). Majority of natural and technogenically transformed soils in the studied area have texture of medium sand according to USDA Soil Taxonomy (Soil Survey Staff 2014), but some have texture of coarse and fine sand. The moderate climate of the region is between the marine type of Western Europe and the continental type of Eastern Europe. The average annual temperature for the whole year was $8.4{ }^{\circ} \mathrm{C}$, while the annual rainfall was $535 \mathrm{~mm}$ (Source: data of the Institute of Meteorology and Water Management: stat.gov.pl).

In general, 42 soils from various parts of the city (Table 1) were sampled between April of 2012 and September 2013 (Fig. 1). In each place, soils sealed with asphalt or concrete, fulfilling criteria of technic hard material (IUSS Working Group WRB 2015) (completely sealed, group A; 15 samples), semi-permeable materials (cobblestones and concrete paving slabs, partially sealed, group B; 11 samples), and reference (non-sealed, group C; 16 samples) soils were selected (Fig. 2). They were situated in direct proximity to ensure similar history of technogenic disturbances, the same environmental conditions, and soil texture. Samples from both categories of sealed soils were collected from the topmost original horizon that was left after the process of construction of sealing surface. Soil samples were collected from a depth of $15-25 \mathrm{~cm}$ or $10-20 \mathrm{~cm}$. Depth of sampling depended on the thickness of the technic hard material combined with the ballast layer used for stabilization of the pavement construction. Reference sites without sealing were located on lawns of green-belts next to pavements or roads (about $1 \mathrm{~m}$ ) to ensure maximum soil comparability. Samples were collected from the same depth as in the sealed soils. The sealing was performed between 30 and 40 years ago, in 1970 or 1980.

\section{Chemical and physical analysis of the soil}

After air-drying at room temperature and sieving $(<2 \mathrm{~mm})$, the soil samples were analyzed for physical and chemical properties. Physicochemical properties were determined using standard methods (Van Reeuwijk 2002). Each soil sample was analyzed in triplicate. Texture was assessed by the areometric method 
Fig. 1 Location of study sites in Toruń, Poland

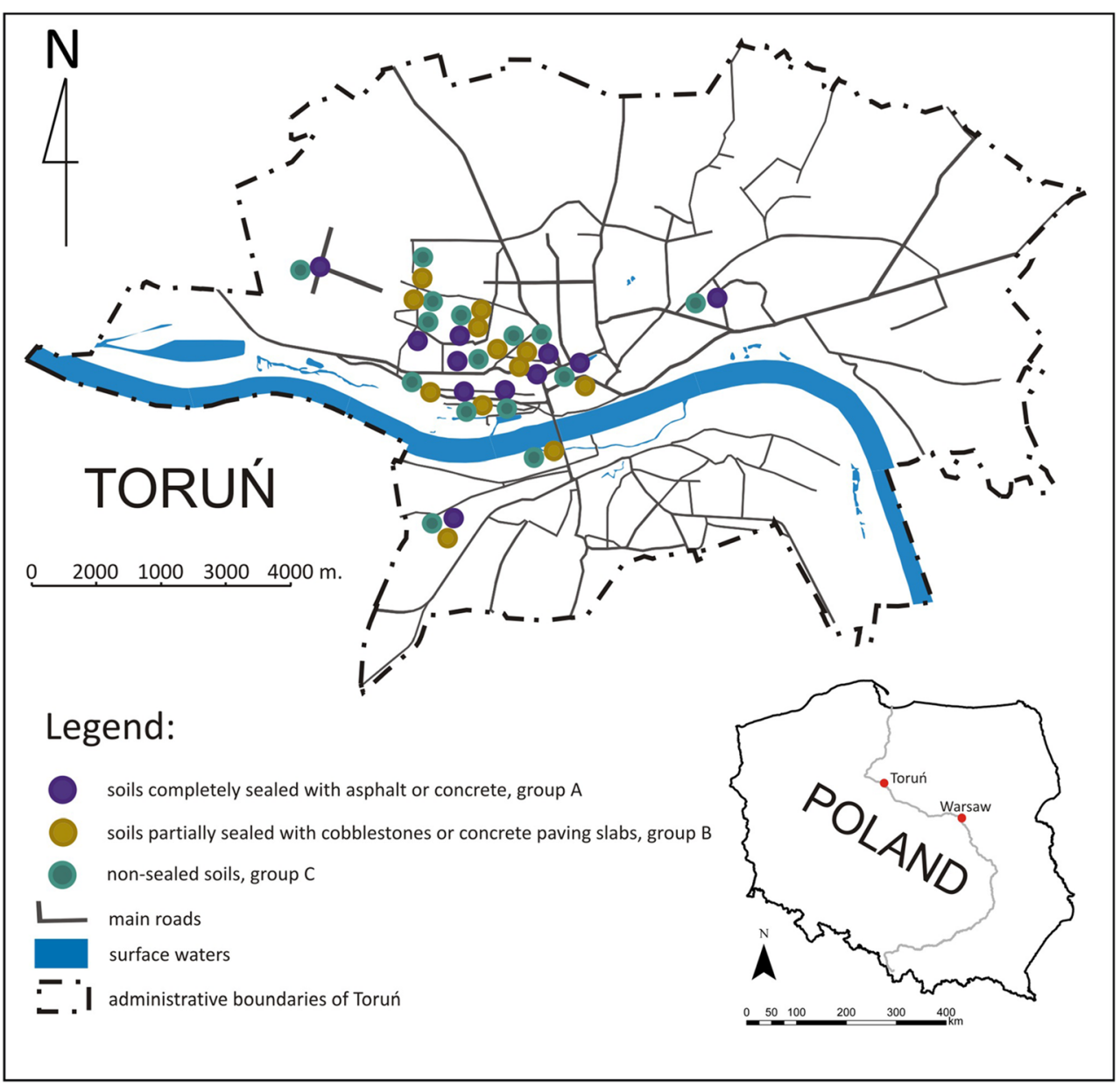

combined with the sieve method. The $\mathrm{pH}$ in $1 \mathrm{~mol}^{-1} \mathrm{KCl}$ was measured using the potentiometric method in 1:2.5 soil:solution suspensions; total organic carbon $\left(\mathrm{OC}_{\mathrm{TOT}}\right)$ and total nitrogen $\left(\mathrm{N}_{\text {TOT }}\right)$ content were determined using a dry combustion $\mathrm{CN}$ analyzer (Vario Max CN). Available phosphorus (P) was assayed using the vanadium-molybdenum method.

\section{Heavy metal analysis}

The total content of heavy metals (denoted by тот) in the soil samples was determined using the ICP MS technique before dissolving with aqua regia.

\section{Data analysis}

$I_{\text {geo }}$ (Muller 1969) is computed using the following equation:

$I_{\text {geo }}=\log _{2}\left[C_{n} / 1.5 \times B_{n}\right]$,

where $C_{\mathrm{n}}$ is the measured concentration of the element in environment and $B_{\mathrm{n}}$ is the geochemical background value in soil.

According to Muller (1969), the $I_{g \text { eo }}$ for each metal is calculated and classified as uncontaminated $\left(I_{\text {geo }} \leq 0\right)$; uncontaminated to moderately contaminated $\left(0<I_{\text {geo }} \leq 1\right)$; moderately contaminated $\left(1<I_{\text {geo }} \leq 2\right)$; moderately to heavily contaminated $\left(2<I_{\text {geo }} \leq 3\right)$; heavily contaminated $\left(3<I_{\text {geo }} \leq 4\right)$; heavily to extremely contaminated $\left(4<I_{\text {geo }} \leq 5\right)$; and extremely contaminated $\left(I_{\text {geo }} \geq 5\right)$.

The EF calculation is expressed below as

$$
\mathrm{EF}=\left[C_{\mathrm{x}} / C_{\text {ref }}\right]_{\text {sample }} /\left[C_{\mathrm{x}} / C_{\text {ref }}\right]_{\text {background }} \text {, }
$$

where $C_{\mathrm{x}}$ is the concentration of the element of interest and $C_{\text {ref }}$ is the concentration of reference element for normalization.

Enrichment factors of heavy metals were calculated for each soil sample relative to the background values of abundance of chemical elements in the local parent rock, choosing Fe as the reference element (according to Kabata-Pendias and Pendias (1999) - $12.9 \mathrm{~g} \mathrm{~kg}^{-1} \mathrm{Fe}$ ).

Geochemical background was determined on the basis of Czarnowska (1996), Kabata-Pendias and Pendias (1999), Lis and Pasieczna (1995) and Pasieczna (2003). There have been analyzed uncultivated areas, taking into account the different geological provinces according to classification proposals used for geochemical map of the world (Damley 1995). The area of Torun is situated in the northern province of the Polish Lowland, where sand is mostly present. 
Table 1 Sampling sites and soil profiles description

\begin{tabular}{|c|c|c|}
\hline Profile no. & Sampling site description & Soil profile description \\
\hline 1 & \multirow{3}{*}{$\begin{array}{l}\text { Bydgoski park; close to the corner of Konopnicka } \\
\text { and Rybaki streets }\end{array}$} & City park, walkway; sealed with asphalt \\
\hline 2 & & Sidewalk; sealed with concrete setts, $30 \times 30 \mathrm{~cm}$ \\
\hline 3 & & City park, grass lawn; control for profile nos. 1 and 2 \\
\hline 4 & \multirow{5}{*}{$\begin{array}{l}\text { Zajęcze Góry park (sand dunes covered mainly } \\
\text { by Scots Pines); close to the corner of Bema and } \\
\text { Gałczyński streets }\end{array}$} & Walkway; sealed with asphalt \\
\hline 5 & & Walkway; sealed with asphalt (on the other side) \\
\hline 6 & & Access street; sealed with concrete slabs $1 \times 1 \mathrm{~m}$ with holes $5 \times 10 \mathrm{~cm}$ \\
\hline 7 & & Sidewalk; sealed with small concrete setts, so-called polbruk \\
\hline 8 & & Roadside greenbelt, grass; control for profile nos. $4,5,6$, and 7 \\
\hline 9 & \multirow[t]{2}{*}{ Bielany suburb; next to Krzemieniecka street } & Roadside; sealed with solid concrete slabs, $30 \times 30 \mathrm{~cm}$ \\
\hline 10 & & Grass plot; control for profile no. 8 \\
\hline 11 & \multirow{3}{*}{$\begin{array}{l}\text { Chełmińskie suburb; recreation area } \\
\text { (playground, basketball field) next to Sportowa street }\end{array}$} & Walkway; sealed with asphalt \\
\hline 12 & & Sidewalk; sealed with concrete setts, $30 \times 30 \mathrm{~cm}$ \\
\hline 13 & & Grass plot; control for profile no. 8 \\
\hline 14 & \multirow{4}{*}{$\begin{array}{l}\text { Nicolaus Copernicus University in Toruń } \\
\text { Campus; recreational area next to dormitories buildings }\end{array}$} & Walkway; sealed with concrete with thin layer of asphalt on the top \\
\hline 15 & & Walkaway; sealed with concrete setts, $40 \times 40 \mathrm{~cm}$ \\
\hline 16 & & Walkaway; sealed with small concrete setts, so-called polbruk \\
\hline 17 & & Grass plot, some pines; control for profile nos. 10 and 11 \\
\hline 18 & \multirow[t]{3}{*}{ Jordanki area; former recreational area, car park } & Square covered with asphalt \\
\hline 19 & & Square covered with large concrete slabs $1 \times 2 \mathrm{~m}$ \\
\hline 20 & & Bare ground, control for profile nos. 18 and 19 \\
\hline 21 & \multirow[t]{2}{*}{ Chełmińskie suburb; near Szosa Chełmińska street } & Sidewalk, granite slabs $70 \times 70 \mathrm{~cm}$ \\
\hline 22 & & Grass plot; control for profile no. 21 \\
\hline 23 & \multirow[t]{2}{*}{ Vistula river left bank flood plain } & Access street to Dybowski castle; sealed with cobblestones \\
\hline 24 & & Meadow with bushes; control for profile nos. 13 and 14 \\
\hline 25 & \multirow{2}{*}{ Bydgoskie suburb; next to Bydgoska street } & Walkway; sealed with concrete \\
\hline 26 & & Roadside greenbelt, grass; control for profile no. 25 \\
\hline 27 & \multirow{3}{*}{$\begin{array}{l}\text { Na Skarpie suburb; constructed in ' } 70 \text { of XX } \\
\text { cent., next to Lubicka street (major, busiest city } \\
\text { thoroughfare), eastern part of city }\end{array}$} & Walkway; sealed with asphalt \\
\hline 28 & & Walkaway; sealed with solid concrete slabs, $30 \times 30 \mathrm{~cm}$ \\
\hline 29 & & Roadside greenbelt, grass; control for profiles nos. 27 and 28 \\
\hline 30 & \multirow{2}{*}{$\begin{array}{l}\text { Rubinkowo suburb; constructed in ' } 70 \text { of XX cent.; next } \\
\text { to Łyskowskiego street, area between four-storey apartment } \\
\text { buildings, eastern part of the city }\end{array}$} & Walkway; sealed with asphalt \\
\hline 31 & & Grass plot with some trees; control for profile no. 30 \\
\hline 32 & \multirow{2}{*}{$\begin{array}{l}\text { Torun airport area; operated by Pomeranian Flying Club, } \\
\text { western part of the city }\end{array}$} & Runaway; sealed with concrete slabs, $3 \times 3 \mathrm{~m}$ \\
\hline 33 & & Meadow; control for profile no. 16 \\
\hline 34 & \multirow{3}{*}{ Podgórz suburb; left bank part of the city } & Access street; sealed with solid concrete slabs \\
\hline 35 & & Access street; sealed with concrete slabs $1 \times 1 \mathrm{~m}$ with holes $5 \times 10 \mathrm{~cm}$, \\
\hline 36 & & Grass plot, control for profile nos. 18 and 19 \\
\hline 37 & \multirow[t]{2}{*}{ Bielany suburb, next to Okrężna street } & Roadside; sealed with solid concrete slabs, $30 \times 30 \mathrm{~cm}$ \\
\hline 38 & & Roadside greenbelt; control for profile no. 21 \\
\hline 39 & \multirow[t]{2}{*}{ Bielany suburb; next to Krzemieniecka street } & Roadside; sealed with concrete slabs, $1 \times 0.75 \mathrm{~m}$ with holes $5 \times 10 \mathrm{~cm}$ \\
\hline 40 & & Roadside greenbelt, grass; control for profile no. 24 \\
\hline 41 & \multirow{2}{*}{$\begin{array}{l}\text { Yard of end of XIX cent. house; the corner } \\
\text { of Konopnicka and Rybaki streets }\end{array}$} & Yard of nineteenth century house; sealed with cobblestone \\
\hline 42 & & Grass lawn; control for profile nos. 1 and 2 \\
\hline
\end{tabular}

Five contamination categories are recognized on the basis of the enrichment factor: $\mathrm{EF}<2$ states deficiency to minimal enrichment, $\mathrm{EF}=2-5-$ moderate enrichment, $\mathrm{EF}=5-20$ significant enrichment, EF $=20-40$-very high enrichment, and EF > 40 extremely high enrichment (Duzgoren-Aydin et al. 2006; Sezgin et al. 2003).

PLI (Tomlinson et al. 1980) is expressed as follows:

$\mathrm{PLI}=\left(\mathrm{CF}_{\mathrm{Cr}} \times \mathrm{CF}_{\mathrm{Ni}} \times \mathrm{CF}_{\mathrm{Cu}} \times \mathrm{CF}_{\mathrm{Zn}} \times \mathrm{CF}_{\mathrm{Cd}} \times \mathrm{CF}_{\mathrm{Pb}} \times \mathrm{CF}_{\mathrm{Hg}}\right)^{1 / 7}$,

where $\mathrm{CF}$ is the contamination factor obtained by calculating between each metal's concentration and its background value.

When PLI is greater than 1 , it means that contamination exists; however, if PLI is less than 1, there is no metal contamination.

\section{Statistical data evaluation}

Data were analyzed using non-parametric tests (Statistica 6.1, Stat Soft. Inc.). Moreover, principal component analysis (PCA) of two factors and cluster analysis (CA) using the Euclidean distance were applied.

\section{Results and discussion}

\section{The basic properties of soils}

The physical and chemical properties of the studied soils are presented in Table 2. The studied soils represented poorly diversified texture distribution, and according to 

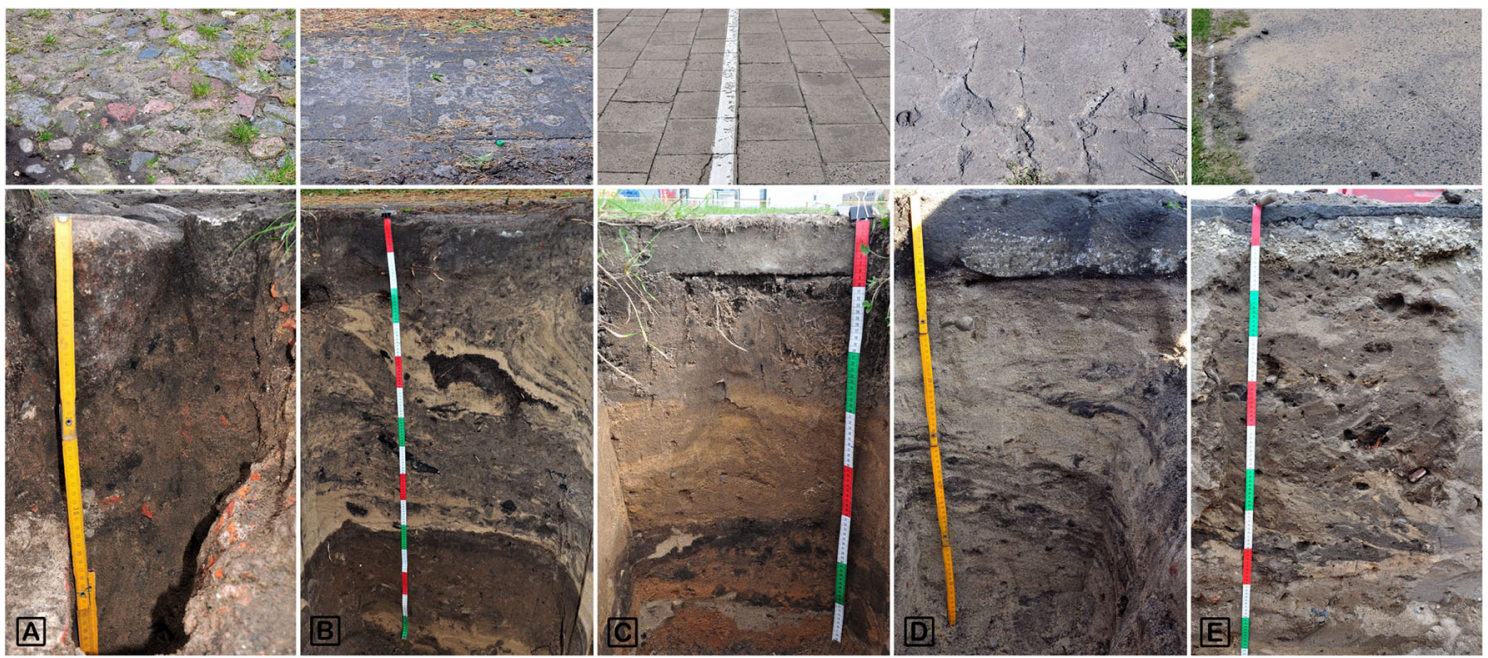

Fig. 2 Examples of sealed soils. Partially sealed soils: A—profile no. 41; B—profile no. 6; C—profile no. 28; completely sealed soils: D-profile no. $19 ;$ E-profile no. 5

the USDA, they represented mainly sand and loamy sand. In the studied profiles, there was a significant presence of the skeleton, which was mostly the building rubble.

There is no difference between the soil groups in the average $\mathrm{pH}$ values (Table 2). Soil sealing significantly reduced the content of $\mathrm{OC}_{\text {TOT }}$ and $\mathrm{N}_{\text {TOT }}$ compared to non-sealed soil. The C:N ratio ranged widely from 9.3 to 28.9 and was not significantly different for the reference and sealed soils, or for both categories of soil sealing (Table 2). Distribution of organic carbon content showed high variability, which is quite typical for the anthropogenic soil (e.g., replenishing a new layer or mixing of soil material) (Greinert 2015). Higher levels of $\mathrm{OC}_{\mathrm{TOT}}$ and $\mathrm{N}_{\mathrm{TOT}}$ in non-sealed soils in relation to other comparable groups can be primarily explained by the lack of barriers in the supply of organic matter but also higher biological activity in the non-sealed soil. The content of available phosphorus, $P_{\mathrm{AV}}$, also showed large range reaching from 47 to $456 \mathrm{mg} \mathrm{kg}^{-1}$, but no clear trend appears between the compared groups of soil.

\section{Relation of soil sealing and heavy metal content}

Heavy metal concentrations in urban soils in Torun are given in Table 3. The total content of heavy metals $(\mathrm{Cd}$, $\mathrm{Cr}, \mathrm{Cu}, \mathrm{Ni}, \mathrm{Pb}, \mathrm{Zn}$ ) in soils of all groups does not exceed the size of the content permitted in Poland (Regulation of the Minister of Environment on soil quality standards and earth quality standards, Dz.U.02.165.1359 dated 04.10.2002). The results were also compared with the permissible content of heavy metals in the soil in the Netherlands and Germany, and no exceeded values were detected (NGG 1995, BBodSchV, 1999).

Analysis of heavy metal content in the three soil groups studied in Torun arranged soil in the following order: group $\mathrm{C}$ (non-sealed) $>$ group A (completely sealed) $>$ group B (partially sealed) (Table 3 ).

The level of geochemical background of heavy metals in relation to the completely sealed soil exhibits higher values for $\mathrm{Cu}, \mathrm{Pb}, \mathrm{Zn}$, and $\mathrm{Hg}$ (Table 3). The highest concentration of heavy metals in all examined

Table 2 Physical and chemical properties of urban soils in Toruń

\begin{tabular}{|c|c|c|c|c|c|c|c|c|}
\hline & & $\begin{array}{l}\text { Sand } \\
(\%)\end{array}$ & Silt & Clay & $\mathrm{pH}_{\mathrm{KCl}}$ & $\begin{array}{l}\mathrm{OC}_{\mathrm{TOT}} \\
\left(\mathrm{g} \mathrm{kg}^{-1}\right)\end{array}$ & $N_{\text {TOT }}$ & $\begin{array}{l}P_{\mathrm{AV}} \\
\left(\mathrm{mg} \mathrm{kg}^{-1}\right)\end{array}$ \\
\hline \multirow[t]{2}{*}{ Gr. A } & Mean & $97.4 \pm 3.4$ & $2.3 \pm 2.7$ & $0.4 \pm 0.7$ & $7.6 \pm 1.15$ & $2.79 \pm 1.67$ & $0.17 \pm 0.09$ & $180 \pm 127$ \\
\hline & Range & $91-100$ & $0-7$ & $0-2$ & $4.6-8.4$ & $1.79-5.10$ & $0.024-0.32$ & $47-460$ \\
\hline \multirow[t]{2}{*}{ Gr. B } & Mean & $98.5 \pm 2.0$ & $1.3 \pm 1.4$ & $0.2 \pm 0.6$ & $7.5 \pm 1.13$ & $2.22 \pm 1.81$ & $0.15 \pm 0.07$ & $98 \pm 31$ \\
\hline & Range & $93-100$ & $0-5$ & $0-2$ & $5.6-8.6$ & $1.31-4.63$ & $0.064-0.30$ & $57-154$ \\
\hline \multirow[t]{2}{*}{ Gr. C } & Mean & $95.5 \pm 4.5$ & $3.8 \pm 3.5$ & $0.2 \pm 0.6$ & $7.6 \pm 0.6$ & $5.60 \pm 2.36$ & $0.36 \pm 0.17$ & $200 \pm 138$ \\
\hline & Range & 88-99 & $1-9$ & $0-2$ & $6.7-8.3$ & $2.24-9.90$ & $0.13-0.72$ & $50-456$ \\
\hline
\end{tabular}

Gr. A — completely sealed soil, Gr. B — partially sealed soil, Gr. C—non-sealed soil. Values are means \pm SD 
Table 3 Heavy metal concentrations in urban soils in Torun

\begin{tabular}{lllllllll}
\hline & & $\begin{array}{l}\mathrm{Cu} \\
\left(\mathrm{mg} \mathrm{kg}^{-1}\right)\end{array}$ & $\mathrm{Pb}$ & $\mathrm{Zn}$ & $\mathrm{Ni}$ & $\mathrm{Cd}$ & $\mathrm{Cr}$ & $\mathrm{Hg}$ \\
\hline Gr. A & Mean & $11.8 \pm 15.3$ & $25.2 \pm 40.4$ & $23.7 \pm 21.5$ & $3.0 \pm 2.0$ & $0.1 \pm 0.3$ & $2.7 \pm 1.5$ & $0.11 \pm 0.2$ \\
& Range & $1.2-56.5$ & $2.8-159.2$ & $4.5-69.5$ & $0.7-7.4$ & $0.01-1.2$ & $1.2-5.7$ & $0.01-0.6$ \\
Gr. B & Mean & $3.0 \pm 1.7$ & $7.9 \pm 6.0$ & $16.5 \pm 9.0$ & $2.2 \pm 1.2$ & $0.1 \pm 0.2$ & $2.4 \pm 1.0$ & $0.03 \pm 0.03$ \\
& Range & $1.3-6.6$ & $2.4-21.4$ & $6.3-35.5$ & $0.9-5.0$ & $0.02-0.9$ & $1.1-4.3$ & $0.01-0.1$ \\
Gr. C & Mean & $9.5 \pm 9.5$ & $25.1 \pm 29.5$ & $41.5 \pm 45.8$ & $3.5 \pm 2.0$ & $0.1 \pm 0.1$ & $3.6 \pm 2.2$ & $0.1 \pm 0.2$ \\
& Range & $1.6-30.9$ & $3.3-100.7$ & $9.5-151.6$ & $0.8-6.5$ & $0.03-0.4$ & $1.1-9.0$ & $0.01-0.7$ \\
Background $^{\mathrm{a}}$ & & 7.10 & 9.80 & 30.00 & 10.20 & 0.18 & 27.00 & 0.06 \\
\hline
\end{tabular}

Gr. A — completely sealed soil, Gr. B — partially sealed soil, Gr. C—non-sealed soil. Values are means \pm SD

a (Czarnowska 1996; Kabata-Pendias and Pendias 1999; Lis and Pasieczna 1995; Pasieczna 2003)

soil groups was detected in the industrial zone of the city and in the locations along roads with heavy traffic. Content of heavy metals in partly sealed soils showed content comparable to the geochemical background. The average content of $\mathrm{Cu}, \mathrm{Pb}, \mathrm{Zn}, \mathrm{Cd}$, and $\mathrm{Hg}$ shows higher values compared with the average value of geochemical background in Poland. Concentration values for the other elements, i.e., $\mathrm{Ni}$ and $\mathrm{Cr}$, were comparable.

Comparison of heavy metal content in sealed soils with other cities in Poland, Germany, Hungary, and Russia shows that the concentration of the analyzed elements in the urban soils of Torun is on a medium level (Table 4).

The $I_{\text {geo }}$ index is used to assess heavy metal contamination in urban soils by comparing current and preindustrial concentrations, although it is not always easy to reach pre-industrial sediment layers. It is also employed in pollution assessment of heavy metals in urban road dust.

In this study, the background geochemical composition of the city soil types (Czarnowska 1996; KabataPendias and Pendias 1999; Lis and Pasieczna 1995;
Pasieczna 2003) is chosen as the local background value for calculating the $I_{\text {geo }}$ values, which are presented in Table 5. The constant equal 1.5 allows to analyze natural fluctuations in the content of a given substance in the environment and to detect very small anthropogenic influences.

The average value of $I_{\text {geo }}$ decreases for soils from group A in the following order: $\mathrm{Pb}>\mathrm{Hg}>\mathrm{Cu}>\mathrm{Cd}=\mathrm{Zn}>\mathrm{Ni}>\mathrm{Cr}$, for soils from group $\mathrm{B}: \mathrm{Pb}=\mathrm{Cd}>\mathrm{Hg}=\mathrm{Zn}>\mathrm{Cu}>\mathrm{Ni}>\mathrm{Cr}$, and for soils from group C as follows: $\mathrm{Pb}>\mathrm{Hg}>\mathrm{Zn}>\mathrm{Cu}>\mathrm{Cd}>\mathrm{Ni}>\mathrm{Cr}$. Despite negative values of $I_{\text {geo }}$ for $\mathrm{Cr}, \mathrm{Ni}, \mathrm{Zn}$, and $\mathrm{Cd}$ in all types of studied soils, they should not be simply classified as "uncontaminated" because such values may be connected with low background concentration of Vistula valley, but not with lack of technogenic accumulation of pollutants. For $\mathrm{Pb}$ and $\mathrm{Hg} I_{\text {geo }}$ values in reference soil and completely sealed soil belonged to the category of "uncontaminated to moderately contaminated," while the average value of $I_{\text {geo }}$ for partially sealed soil was indicated as "uncontaminated." This means that the results obtained for each of the elements are considerably different. In the case of

Table 4 Mean heavy metal concentrations in topsoil of sealed urban soils from some European cities

\begin{tabular}{|c|c|c|c|c|c|c|c|c|}
\hline & $\begin{array}{l}\mathrm{Cr}_{\mathrm{TOT}} \\
\left(\mathrm{mg} \mathrm{kg}^{-1}\right)\end{array}$ & $\mathrm{Zn}_{\mathrm{TOT}}$ & $\mathrm{Cd}_{\mathrm{TOT}}$ & $\mathrm{Pb}_{\mathrm{TOT}}$ & $\mathrm{Cu}_{\mathrm{TOT}}$ & $\mathrm{Hg}_{\text {тот }}$ & $\mathrm{Ni}_{\mathrm{TOT}}$ & Reference \\
\hline Toruń, Poland & 2.73 & 23.75 & 0.15 & 25.23 & 11.8 & 0.12 & 3.05 & This study \\
\hline Szczecin, Poland & n.a. & 42.6 & 0.28 & 29.1 & 25.8 & n.a. & 21.8 & Sammel et al. 2013 \\
\hline Szczecin, Poland & n.a. & 28.8 & 0.29 & 18 & 8.07 & n.a. & 8.17 & Meller et al. 2013 \\
\hline Zielona Góra, Poland & n.a. & 293 & 0.58 & 85.2 & 33 & n.a. & 9.7 & Greinert 2013 \\
\hline Debrecen, Hungary & 8 & 67.7 & $<1$ & 10.3 & 7.1 & n.a. & 4.58 & Sandor et al. 2013 \\
\hline Hannover, Germany & n.a. & 186 & 1.2 & 172 & 52 & n.a. & 20 & Wesolek 2008 \\
\hline Moscow, Russia & n.a. & 58.2 & 0.3 & 74.2 & 24.1 & n.a. & 1.9 & Stroganova et al. 1998 \\
\hline Rostov, Russia & 84.2 & 68.8 & n.a. & 15.9 & 28.0 & n.a. & 25.2 & Bezuglova et al. 2016 \\
\hline
\end{tabular}

TOT total, n.a. data not available 
Table 5 Geoaccumulation index $\left(I_{\text {geo }}\right)$ of heavy metals in urban soils in Toruń

\begin{tabular}{lllllllll}
\hline & $\mathrm{Cu}$ & $\mathrm{Pb}$ & $\mathrm{Zn}$ & $\mathrm{Ni}$ & $\mathrm{Cd}$ & $\mathrm{Cr}$ & $\mathrm{Hg}$ \\
\hline Gr. A & Mean & 0.1 & 0.8 & -0.9 & -2.3 & -0.9 & -3.9 & 0.3 \\
& Range & $(-3.2)-2.4$ & $(-2.4)-3.4$ & $(-3.3)-0.6$ & $(-4.5)-(-1.1)$ & $(-4.8)-2.2$ & $(-5.1)-(-2.8)$ & $(-4.2)-2.6$ \\
Gr. B & Mean & -0.6 & -0.3 & -0.4 & -0.8 & -0.3 & -1.2 &.-0.4 \\
& Range & $(-3.1)-(-0.7)$ & $(-2.6)-0.5$ & $(-2.8)-(-0.3)$ & $(-4.1)-(-1.6)$ & $(-3.8)-1.7$ & $(-5.2)-(-3.2)$ & $(-3.0)-0.1$ \\
Gr. C & Mean & -0.2 & 0.8 & -0.1 & -2.2 & -1.0 & -3.5 & 0.6 \\
& Range & $(-2.7)-1.5$ & $(-2.2)-2.8$ & $(-2.2)-1.8$ & $(-4.3)-(-1.2)$ & $(-3.2)-0.6$ & $(-5.2)-(-2.2)$ & $(-3.0)-2.9$ \\
\hline
\end{tabular}

Gr. A—completely sealed soil, Gr. B — partially sealed soil, Gr. C—non-sealed soil

$\mathrm{Cu}, I_{\text {geo }}$ in the group of sealed soils had a value higher than zero ("uncontaminated to moderately contaminated").

Generally, low average values of $I_{\text {geo }}$ in all examined groups of soil in Torun have indicated a small level of soil contamination with heavy metals. Simultaneously, it is worth noting that on the basis of the maximum value of $I_{\text {geo }}$ for $\mathrm{Cu}, \mathrm{Cd}, \mathrm{Pb}, \mathrm{Hg}$, and $\mathrm{Zn}$, sealed soil is classified as "moderately to heavily contaminated." Moreover, the contamination of $\mathrm{Pb}$ and $\mathrm{Zn}$ are associated (Fig. 4). It probably means that they have the same source, i.e., cars, but accumulation occurred at different chronological periods, which could be associated with the motor fuel quality (unleaded petrol). Comparison of average $I_{\text {geo }}$ value among the three groups of soil indicates a following order: partially sealed soil (group B) < non-sealed soil (group C) < completely sealed soil (group A).

\section{Environmental risk assessment of studied soils}

A great number of environmental risk assessment is known in the literature (Hilton et al. 1985; Tomlinson et al. 1980; Verca and Dolence 2005); therefore, the character of the analyzed area was taken into account, and two factors, EF and PLI, were chosen for the evaluation of the soil sealing.

The EF factor evaluated heavy metal pollution according to the content of heavy metals, but it hardly distinguished their source, chemical activity, or biological availability. The main advantage of EF application is the possibility to compare the results with the data presented by other researchers.

Calculation of EF was based on the standardization of a measured element against a reference element. A reference element is often the one characterized by low occurrence variability, such as $\mathrm{Al}, \mathrm{Fe}, \mathrm{Ti}, \mathrm{Si}, \mathrm{Sr}$, and $\mathrm{K}$ (Duzgoren-Aydin 2007; Sezgin et al. 2003). EF values less than 5.0 are not considered significant, because such small enrichments may arise from differences in the composition of local soil material and reference soil used in EF calculations (Sezgin et al. 2003). However, there is no accepted pollution ranking system or categorization of degree of pollution on the enrichment ratio and/or factor methodology.

The calculated values of EF are presented in Table 6. In the completely sealed soil, average EF values decreased in the following order: $\mathrm{Pb}>\mathrm{Hg}>\mathrm{Cu}>\mathrm{Cd}>\mathrm{Ni}>\mathrm{Zn}>\mathrm{Cr}$, while in the partially sealed soil, as follows: $\mathrm{Pb}>\mathrm{Cd}>\mathrm{Hg}>$ $\mathrm{Zn}>\mathrm{Cu}>\mathrm{Ni}>\mathrm{Cr}$. The average value of the EF for nonsealed soil showed the following diminishing order: $\mathrm{Pb}>\mathrm{Hg}>\mathrm{Zn}>\mathrm{Cu}>\mathrm{Cd}>\mathrm{Ni}>\mathrm{Cr}$, similar to the order described for $I_{\text {geo. }}$. The analysis of EF values have indicated that the content of chromium in all examined groups of soil states "deficiency to minimal enrichment," whereas the average values of EF for $\mathrm{Zn}$, $\mathrm{Ni}$ and $\mathrm{Cd}$ have been in the range from 2 to 5 , what is called the level of "moderate enrichment." In the completely sealed soil, the average value of the $\mathrm{EF}$ for $\mathrm{Hg}, \mathrm{Cu}$, and $\mathrm{Pb}$ has been greater than 5, which clearly shows that these elements are derived from anthropogenic sources. In partially sealed soil, only $\mathrm{Pb}$ has

Table 6 Enrichment factor (EF) and pollution load index (PLI) of heavy metals in urban soils in Torun

\begin{tabular}{llllllllll}
\hline & & $\mathrm{Cu}$ & $\mathrm{Pb}$ & $\mathrm{Zn}$ & $\mathrm{Ni}$ & $\mathrm{Cd}$ & $\mathrm{Cr}$ & $\mathrm{Hg}$ \\
& & $\mathrm{EF}$ & & & & & PLI \\
\hline Gr. A & Mean & 5.1 & 7.0 & 2.8 & 4.0 & 4.1 & 0.4 & 5.4 \\
& Range & $1.0-16.3$ & $1.4-16.4$ & $1.3-6.4$ & $0.7-10.2$ & $0.5-42.7$ & $0.2-0.6$ & $0.4-16.1$ & $0.1-2.3$ \\
Gr. B & Mean & 2.5 & 5.5 & 3.4 & 1.2 & 3.8 & 0.5 & 3.5 \\
& Range & $1.1-4.4$ & $1.0-20.1$ & $1.1-6.4$ & $0.8-1.6$ & $0.7-25.7$ & $0.4-0.7$ & $0.8-8.6$ & 0.1 \\
Gr. C & Mean & 4.1 & 7.6 & 4.4 & 1.2 & 2.7 & 0.5 & 6.1 & 0.9 \\
& Range & $1.0-9.4$ & $1.1-22.1$ & $1.3-13.8$ & $0.7-1.7$ & $1.0-10.0$ & $0.3-0.6$ & $0.9-22.0$ & $0.2-2.8$ \\
\hline
\end{tabular}

Gr. A—completely sealed soil, Gr. B — partially sealed soil, Gr. C—non-sealed soil 


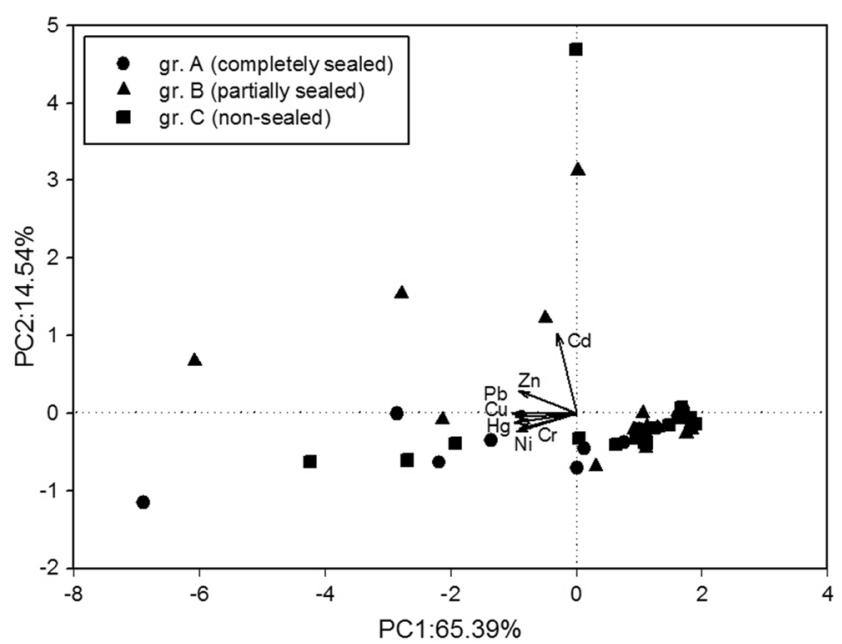

Fig. 3 Principal component analysis (PCA) of two factors

shown anthropogenic origin, and in the reference soil, average $\mathrm{EF}$ index above 5 has been observed for $\mathrm{Pb}$ and $\mathrm{Cu}$. It seems, therefore, that $\mathrm{EF}$ can also be an effective indicator used to distinguish the natural origin of anthropogenic sources of heavy metals.

The PLI index was evaluated to assess the mutual contamination effects of the seven metals measured in this study.

Mean of PLI (Table 6) was the highest in the non-sealed soils and arranged in the decreasing order as follows: group $\mathrm{C}$ $>$ group A > group B, which showed that the non-sealed soils occurred the most contaminated ones. Furthermore, the largest concentrations of pollutants such as polycyclic aromatic hydrocarbons (PAHs) and the greatest biological activity were detected in non-sealed soils in Torun (Mendyk and
Charzyński 2016; Piotrowska-Długosz and Charzyński 2015). The sealing of the soil accompanied limitation of the migration of heavy metals in the soil profile due to the reduction of the supply of the surface levels, limitation of water movement, increase in the specific density of the soil, and the reduction of the degree of aeration. Hence, we can conclude that higher concentrations of $\mathrm{Hg}, \mathrm{Cu}$, and $\mathrm{Pb}$ have been derived from anthropogenic sources before sealing the soil. It was observed that the content of heavy metals in all soil groups has often been significantly different. This could depend mainly on the type of substrate (e.g., debris, garbage, waste) and the origin of the pollutants such as sewage, sludge, and road traffic, which are characteristics for urban soils (Luo et al. 2012b). Similar conclusions were presented by Bezuglova et al. (2016) who studied sealed and non-sealed soil in Rostov-on-Don. Total contamination factor $Z_{\mathrm{c}}$ (Revich et al. 1985) was used to show that the sealing of urban soils reduces the vertical migration of heavy metals in the soil profile. The determination of the level of risk of soil contamination with heavy metals depends on their content in the parent rock and on the technogenic deposition in the surface layers. In soils of Rostov-on-Don developed on loess, the content of heavy metals in parent rock was higher than the geochemical background (Bezuglova et al. 2016).

Data were evaluated using classical statistical methods. They did not show a normal distribution according to the ShapiroWilk test; thus, they were analyzed using non-parametric Kruskal-Wallis test, but any statistically significant differences were detected. Moreover, PCA of two factors, CA analysis using the Euclidean distance (Lee et al. 2006; Zheng et al. 2008), and Spearman's correlation coefficients were applied.
Fig. 4 Hierarchical dendrogram for seven heavy metals obtained by cluster analysis (CA)

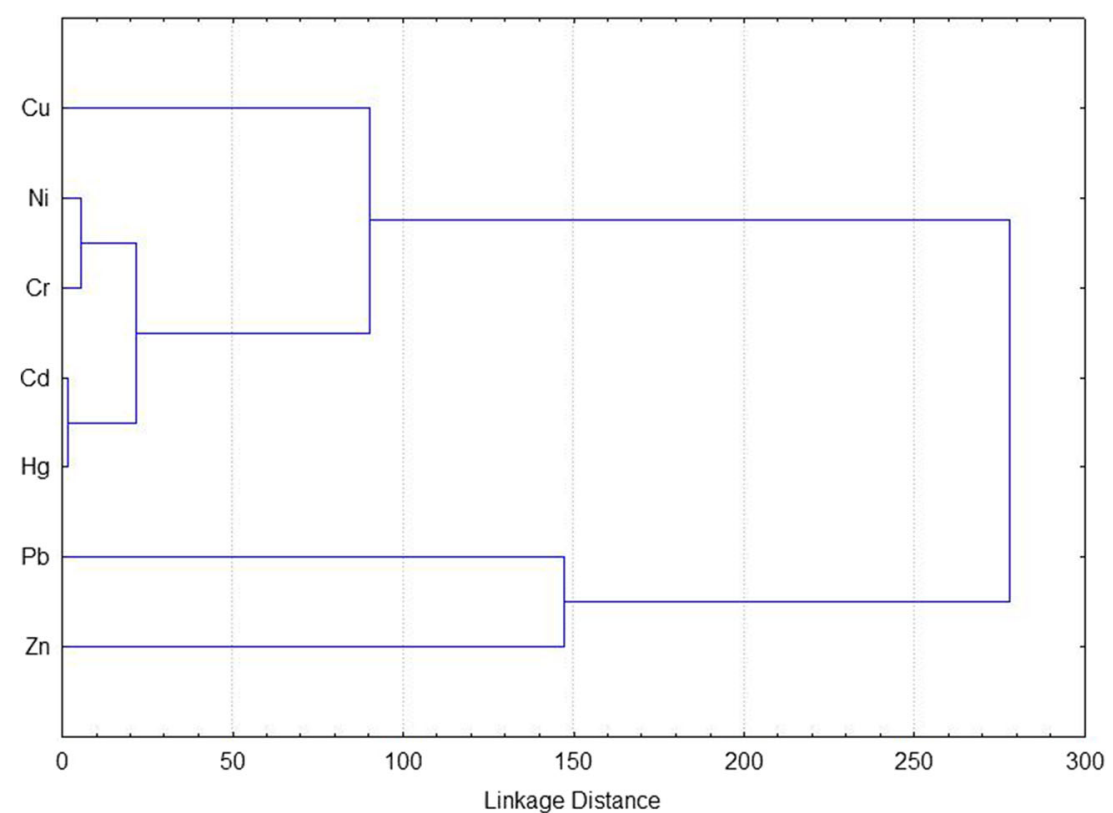


In PCA analysis, all heavy metals were represented by the first two principal components, which accounted for $79.9 \%$ of the total variance. Nevertheless, factors 1 and 2, which explained 65.4 and $14.5 \%$ of total variance, respectively, did not differentiate types of soil on the basis of the content of heavy metals (Fig. 3). The result of CA analysis is illustrated in Fig. 4, on which two distinct clusters can be identified. Cluster I contained $\mathrm{Cd}, \mathrm{Cr}, \mathrm{Cu} \mathrm{Ni}$, and $\mathrm{Hg}$, while the long distance between $\mathrm{Cu}$ and the other four heavy metals suggested that this cluster could be further divided into two sub-clusters. Cluster II contained $\mathrm{Pb}$ and $\mathrm{Zn}$. Concentrations of $\mathrm{Cu}, \mathrm{Pb}$, and $\mathrm{Hg}$ were significantly higher than the background values of Poland, and concentrations of $\mathrm{Cr}, \mathrm{Cd}, \mathrm{Ni}$, and $\mathrm{Zn}$ were comparable to the background values. Therefore, previously described $\mathrm{EF}$ and $I_{\text {geo }}$ indexes show that the distribution of $\mathrm{Cu}, \mathrm{Pb}$, and $\mathrm{Hg}$ in urban soils of Torun was affected mostly by anthropogenic sources, while $\mathrm{Cr}, \mathrm{Cd}, \mathrm{Ni}$, and $\mathrm{Zn}$ were mainly from natural sources.
Moreover, significant Spearman's correlations between heavy metal content and physical properties of the urban soil in Torun (Table 7) were determined mainly in nonsealed soil and then for completely sealed soil. In partially sealed soil, the amount of correlations was the least. However, partial or complete sealing did not differentiate the soil in terms of heavy metal content, which confirmed the idea that the soil is heterogeneous under technopressure and remains in contrast to the soil formed under natural conditions. Similarly, the results analyzed in the population of non-sealed soil were the evidence of their high heterogeneity. Soil sealing interrupts the exchange between the soil system and other ecological compartments, including the biosphere, hydrosphere, and atmosphere, which affects processes in the water cycle, biogeochemical cycles, and energy transfers (Siebielec et al. 2015). However, in case of the impact of sealing of urban soils on the content of heavy metals, we proved only slight effect.

Table 7 The values of Spearman's correlation coefficients between heavy metal concentrations and physical properties of urban soils in Torun (significance level $0.05, p<0.05$ )

\begin{tabular}{|c|c|c|c|c|c|c|c|c|c|c|c|c|c|}
\hline & $\begin{array}{l}\mathrm{Cu} \\
(\mathrm{ppm})\end{array}$ & $\mathrm{Pb}$ & $\mathrm{Zn}$ & $\mathrm{Ni}$ & $\mathrm{Cd}$ & $\mathrm{Cr}$ & $\begin{array}{l}\mathrm{Hg} \\
(\mathrm{ppb})\end{array}$ & $\begin{array}{l}\text { Sand } \\
(\%)\end{array}$ & Silt & Clay & $\begin{array}{l}\mathrm{P} \\
\left(\mathrm{mg} \mathrm{kg}^{-1}\right)\end{array}$ & $\begin{array}{l}\mathrm{C}_{\text {org }} \\
(\%)\end{array}$ & $\mathrm{N}$ \\
\hline \multicolumn{14}{|l|}{ Gr. A } \\
\hline $\mathrm{Cu}$ & 1 & & & & & & & & & & & & \\
\hline $\mathrm{Pb}$ & 0.93 & 1 & & & & & & & & & & & \\
\hline $\mathrm{Zn}$ & 0.86 & 0.86 & 1 & & & & & & & & & & \\
\hline $\mathrm{Ni}$ & 0.76 & 0.71 & 0.85 & 1 & & & & & & & & & \\
\hline $\mathrm{Cd}$ & 0.70 & 0.74 & 0.86 & 0.72 & 1 & & & & & & & & \\
\hline $\mathrm{Cr}$ & 0.73 & 0.74 & 0.89 & 0.91 & 0.72 & 1 & & & & & & & \\
\hline $\mathrm{Hg}$ & 0.82 & 0.90 & 0.79 & 0.56 & 0.71 & 0.62 & 1 & & & & & & \\
\hline Sand $(\%)$ & -0.43 & -0.58 & -0.53 & -0.54 & -0.48 & -0.45 & -0.50 & 1 & & & & & \\
\hline Silt (\%) & 0.41 & 0.54 & 0.51 & 0.51 & 0.44 & 0.42 & 0.49 & -0.98 & 1 & & & & \\
\hline Clay $(\%)$ & 0.59 & 0.70 & 0.69 & 0.70 & 0.52 & 0.70 & 0.70 & -0.73 & 0.74 & 1 & & & \\
\hline $\mathrm{P}\left(\mathrm{mg} \mathrm{kg}^{-1}\right)$ & 0.77 & 0.82 & 0.53 & 0.44 & 0.30 & 0.39 & 0.75 & -0.41 & 0.38 & 0.55 & 1 & & \\
\hline $\mathrm{C}_{\mathrm{org}}(\%)$ & 0.72 & 0.77 & 0.75 & 0.73 & 0.67 & 0.59 & 0.71 & -0.67 & 0.62 & 0.71 & 0.64 & 1 & \\
\hline $\mathrm{N}(\%)$ & 0.48 & 0.57 & 0.50 & 0.62 & 0.43 & 0.46 & 0.61 & -0.51 & 0.46 & 0.71 & 0.61 & 0.85 & 1 \\
\hline \multicolumn{14}{|l|}{ Gr. B } \\
\hline $\mathrm{Cu}$ & 1 & & & & & & & & & & & & \\
\hline $\mathrm{Pb}$ & 0.55 & 1 & & & & & & & & & & & \\
\hline $\mathrm{Zn}$ & 0.66 & 0.37 & 1 & & & & & & & & & & \\
\hline $\mathrm{Ni}$ & 0.53 & -0.21 & 0.27 & 1 & & & & & & & & & \\
\hline $\mathrm{Cd}$ & 0.85 & 0.51 & 0.81 & 0.48 & 1 & & & & & & & & \\
\hline $\mathrm{Cr}$ & 0.48 & -0.14 & 0.12 & 0.95 & 0.39 & 1 & & & & & & & \\
\hline $\mathrm{Hg}$ & 0.54 & 0.74 & 0.29 & -0.03 & 0.34 & 0.07 & 1 & & & & & & \\
\hline Sand (\%) & -0.67 & -0.09 & -0.32 & -0.83 & -0.50 & -0.78 & -1.00 & 1 & & & & & \\
\hline Silt (\%) & 0.67 & 0.09 & 0.32 & 0.83 & 0.50 & 0.78 & -0.78 & 0.78 & 1 & & & & \\
\hline Clay $(\%)$ & 0.54 & -0.04 & 0.03 & 0.66 & 0.29 & 0.68 & -0.34 & 0.34 & 0.05 & 1 & & & \\
\hline $\mathrm{P}\left(\mathrm{mg} \mathrm{kg}^{-1}\right)$ & 0.66 & 0.66 & 0.54 & 0.14 & 0.66 & 0.17 & -0.19 & 0.19 & 0.06 & 0.55 & 1 & & \\
\hline $\mathrm{C}_{\mathrm{org}}(\%)$ & 0.20 & 0.65 & 0.03 & -0.09 & 0.13 & 0.15 & -0.19 & 0.19 & 0.12 & 0.30 & 0.56 & 1 & \\
\hline $\mathrm{N}(\%)$ & 0.36 & 0.80 & 0.01 & -0.05 & 0.32 & 0.13 & -1.00 & 0.78 & 0.05 & 0.44 & 0.61 & 0.86 & 1 \\
\hline \multicolumn{14}{|l|}{ Gr. C } \\
\hline $\mathrm{Cu}$ & 1 & & & & & & & & & & & & \\
\hline $\mathrm{Pb}$ & 0.79 & 1 & & & & & & & & & & & \\
\hline $\mathrm{Zn}$ & 0.84 & 0.80 & 1 & & & & & & & & & & \\
\hline $\mathrm{Ni}$ & 0.78 & 0.55 & 0.61 & 1 & & & & & & & & & \\
\hline $\mathrm{Cd}$ & 0.81 & 0.76 & 0.78 & 0.75 & 1 & & & & & & & & \\
\hline $\mathrm{Cr}$ & 0.78 & 0.54 & 0.61 & 0.96 & 0.66 & 1 & & & & & & & \\
\hline $\mathrm{Hg}$ & 0.76 & 0.86 & 0.77 & 0.61 & 0.68 & 0.61 & 1 & & & & & & \\
\hline Sand $(\%)$ & -0.65 & -0.47 & -0.50 & -0.88 & -0.69 & -0.83 & -0.63 & 1 & & & & & \\
\hline Silt (\%) & 0.66 & 0.49 & 0.50 & 0.87 & 0.68 & 0.79 & 0.66 & -0.98 & 1 & & & & \\
\hline Clay $(\%)$ & 0.65 & 0.40 & 0.54 & 0.87 & 0.51 & 0.85 & 0.57 & -0.88 & 0.87 & 1 & & & \\
\hline $\mathrm{P}\left(\mathrm{mg} \mathrm{kg}^{-1}\right)$ & 0.78 & 0.78 & 0.87 & 0.50 & 0.58 & 0.57 & 0.76 & -0.42 & 0.42 & 0.55 & 1 & & \\
\hline $\mathrm{C}_{\mathrm{org}}(\%)$ & 0.66 & 0.76 & 0.41 & 0.45 & 0.58 & 0.41 & 0.56 & -0.43 & 0.43 & 0.30 & 0.55 & 1 & \\
\hline $\mathrm{N}(\%)$ & 0.66 & 0.69 & 0.39 & 0.54 & 0.55 & 0.47 & 0.51 & -0.55 & 0.56 & 0.44 & 0.51 & 0.96 & 1 \\
\hline
\end{tabular}

Significant correlations are printed in italics. Gr. A—completely sealed soil, Gr. B—partially sealed soil, Gr. C—non-sealed soil 
The sources of $\mathrm{Cd}, \mathrm{Cu}, \mathrm{Cr}, \mathrm{Hg}, \mathrm{Ni}, \mathrm{Pb}$, and $\mathrm{Zn}$ in urban soils of Torun are extremely heterogenous, and thus, situation is rather complicated. Anthropogenic sources such as vehicle exhaust, household waste, and construction activities have made the heavy metal concentrations higher than their background values. Besides, as Torun is a city with a long history, and the historical buildings such as palaces and temples are all well-preserved, the historical use of heavy metals in pigments, wood preservation, and brassware would also play an important role for their accumulation in urban soils around.

\section{Conclusion}

To assess the status of environmental quality in the completely and partially sealed and non-sealed soils, three indicators, $I_{\text {geo, }}$, $\mathrm{EF}$, and PLI, and multifactorial statistical analysis, were used. The results indicate that the artificial sealing in urban areas slightly affects the content of heavy metals in soils. However, based on PLI, it was found that the sealing has influence on soil properties and non-sealed soil is the most exposed to the accumulation of pollutants. Determination of EF index has also become an effective indicator used to distinguish the natural origin from anthropogenic sources of heavy metals. In our studies, it was found that in completely sealed soils, heavy metals $(\mathrm{Hg}, \mathrm{Cu}, \mathrm{Pb})$ were of anthropogenic origin. Similar pattern was detected for $I_{\text {geo }}$; thus, for completely sealed soils, it decreased in the following order: $\mathrm{Pb}>\mathrm{Cu}>\mathrm{Hg}>\mathrm{Cd}>\mathrm{Zn}>\mathrm{Ni}>\mathrm{Cr}$, for the partially sealed soil: $\mathrm{Pb}>\mathrm{Cd}>\mathrm{Hg}>\mathrm{Zn}>\mathrm{Cu}>\mathrm{Ni}>\mathrm{Cr}$, while for the reference soil: $\mathrm{Pb}>\mathrm{Hg}>\mathrm{Zn}>\mathrm{Cu}>\mathrm{Cd}>\mathrm{Ni}>\mathrm{Cr}$.

Open Access This article is distributed under the terms of the Creative Commons Attribution 4.0 International License (http:// creativecommons.org/licenses/by/4.0/), which permits unrestricted use, distribution, and reproduction in any medium, provided you give appropriate credit to the original author(s) and the source, provide a link to the Creative Commons license, and indicate if changes were made.

\section{References}

Bezuglova OS, Gorbov SN, Tischenko SA, Aleksikova AS, Tagiverdiev SS, Sherstnev AK, Dubinina MN (2016) Accumulation and migration of heavy metals in soils of the Rostov region, south of Russia. J Soils Sediments 16:1203-1213

B. Bod. Sch. V (1999 ) BBodSchV-Bundes-Bodenschutz- und Altlastenverordnung. Vom 12. (BGB1. I 1999 S. 1554)

Charzyński P, Hulisz P, Bednarek R (2013) Technogenic soils of Poland. Polish Society of Soil Science. Toruń, Poland

Czarnowska K (1996) Total content of heavy metals in parent rocks as reference background levels of soils. Soil Sci Ann 47:43-50 [in Polish]

Darnley A, Bjorklund A, Bolviken B, Gustavsson N, Koval PV, Plant JA, Steenfelt A, Tauchid M, Xie Xuejing (1995) A global geochemical database for environmental and resource management. Recommendations for International Geochemical Mapping. Final Report of IGCP Project 259. Earth Sciences 19, UNESCO Publishing, Ottawa

Duzgoren-Aydin NS (2007) Sources and characteristics of lead pollution in the urban environment of Guangzhou. Sci Total Environ 385: $182-195$

Duzgoren-Aydin NS, Wong CSC, Aydin A, Song Z, You M, Li XD (2006) Heavy metal contamination and distribution in the urban environment of Guangzhou, SE China. Environ Geochem Hlth 28: 375-391

Greinert A (2013) Technogenic soils in Zielona Góra. In: Charzyński P, Markiewicz M, Świtoniak M (eds) Technogenic soils atlas. Polish Society of Soil Science, Torun, Poland, pp. 141-164

Greinert A (2015) The heterogeneity of urban soils in the light of their properties. J Soils Sediments 15(8):1725-1737

Hilton J, Davison W, Ochsenbein U (1985) A mathematical model for analysis of sediment core data: implications for enrichment factor calculation and trace metal trans harbor mechanisms. Chem Geol 48:281-291

Horckmans L, Swennen R, Deckers J, Maquil R (2005) Local background concentration of trace elements in soils: a case study in the Grand Duchy of Luxembourg. Catena 59:279-304

IUSS Working Group WRB (2015) World Reference Base for Soil Resources 2014, update 2015. International soil classification system for naming soils and creating legends for soil maps. World Soil Resources Reports No. 106. FAO, Rome

Kabata-Pendias A, Pendias H (1999) Biogeochemistry of trace elements. PWN, Warsaw [in Polish]

Lee CS, Li XD, Shi WZ, Cheung SC, Thornton I (2006) Metal contamination in urban, suburban, and country park soils of Hong Kong: a study based on GIS and multivariate statistics. Sci Total Environ 356:45-61

Lis J, Pasieczna A (1995) The geochemical atlases of Poland 1:2 500000. Polish Geological Institute, Grzegorczyk A (ed), Warsaw

Luo X, Yu S, Li X (2012a) The mobility, bioavailability, and human bioaccessibility of trace metals in urban soils of Hong Kong. Appl Geochem 27:995-1004

Luo X, Yu S, Zhu Y, Li X (2012b) Trace metal contamination in urban soils of China. Sci Total Environ 421-422:17-30

Madrid L, Diaz-Barrientos E, Reinoso R, Madrid F (2004) Metal in urban soils of Sevilla: seasonal changes and relations with other soil components and plant contents. European J Soil Sci 55:209-220

Madrid F, Biasioli M, Ajmone-Marsan F (2008) Availability and bioaccessibility of metals in fine particles of some urban soils. Arch Environ Con Tox 55:21-32

Meller E, Malinowski R, Niedźwiecki E, Malinowska K, Kubus M (2013) Technogenic soils in Szczecin. In: Charzyński P, Markiewicz M, Świtoniak M (eds) Technogenic soils atlas. Polish Society of Soil Science, Toruń, Poland, pp. 93-111

Mendyk $€$, Charzyński P (2016) Soil sealing degree as factor influencing urban soil contamination with polycyclic aromatic hydrocarbons (PAHs). Soil Sci Ann 67(1):17-23

Muller G (1969) Index of geo-accumulation in sediments of the Rhine River. Geol J 2:108-118

Nestroy O (2006) Soil sealing in Austria and its consequences. Ecohydrol Hydrobiol 6(1-4):171-173

NGG [Netherlands Government Gazette] (1995) Circular on intervention values for soil remediation, no. 95

Pasieczna A (2003) Atlas of urban soils contamination in Poland. Polish Geological Institute, Warsaw

Piotrowska-Długosz A, Charzyński P (2015) The impact of the soil sealing degree on microbial biomass, enzymatic activity, and physicochemical properties in the Ekranic Technosols of Torun (Poland). J Soils Sediments 15(1):47-59 
Plak A, Chodorowski J, Melke J, Bis M (2015) Influence of land use on the content of select forms of $\mathrm{Cd}, \mathrm{Cr}, \mathrm{Cu}, \mathrm{Ni}, \mathrm{Pb}$, and $\mathrm{Zn}$ in urban soils. Pol J Environ Stud 24(6):2577-2586

Puskás I, Farsang A (2009) Diagnostic indicators for characterizing urban soils of Szeged, Hungary. Geoderma 148:267-281

Regulation of the Minister of Environment (2002) Dated 09 September 2001 on soil quality standards and quality standards of soil. Journal of Laws 165:1359

Reimann C, Filzmoser P, Garrett RG (2005) Background and threshold: critical comparison of methods of determination. Sci Total Environ 346:1-16

Sammel A, Choragwicki Ł, Niedźwiecki E, Meller E, Malinowski R (2013) Morphological features and chemical properties of soils sealed with bituminous surface (ekranosols) within Obrońców Stalingradu street in Szczecin. Folia Pomeranae Univ Technol Stetinensis Agric Alimentaria Piscaria Zootech 307(28):75-90 [in Polish with English abstract]

Sándor G, Szabo G, Charzyński P, Szynkowska E, Novak TJ, Świtoniak M (2013) Technogenic soils in Debrecen. In: Charzyński P, Markiewicz M, Świtoniak M (eds) Technogenic soils atlas. Polish Society of Soil Science, Toruń, Poland, pp. 35-75

Sauerwein M (2011) Urban soils - characterisation, pollution, and relevance in urban ecosystems. In: Niemela J, Breuste JH, Elmqvist T et al (eds) Urban ecology: patterns, processes, and applications. Willey, New York, pp. 45-58

Sezgin N, Ozcan HK, Demir G, Nemlioglu S, Bayat C (2003) Determination of heavy metal concentrations in street dusts in Istanbul E-5 highway. Environ Int 29:979-985

Siebielec G, Gundula P, Delden H, Verzandvoort S, Miturski T, Łopatka A (2015) Soil sealing. In: Stolte J, Tesfai M, Øygarden L, Kværnø S, Keizer J, Verheijen F, Panagos P, Ballabio C, Hessel R (eds) Soil threats in Europe: status, methods, drivers and effects on ecosystem services. European Commission, 27607 EN; p. 207 doi:10.2788 /488054 (print); doi:10.2788/828742 (online)
Soil Survey Staff (2014) Keys to Soil Taxonomy, 12th ed. USDA-Natural Resources Conservation Service, Washington, DC

Stroganova MN, Miagkova AD, Prokof'eva TV, Skvortsova IN (1998) Soils of Moscow and urban environment. PAIMS, Moscow, pp. 1178

Tomlinson DC, Wilson JG, Harris CR, Jeffrey DW (1980) Problems in the assessment of heavy metals in estuaries and the formation pollution index. Helgoland Mar Res 33:566-575

Van Reeuwijk LP (2002) Procedures for soil analysis. International Soil Reference and Information Centre (ISRIC), Wageningen

Verca P, Dolence T (2005) Geochemical estimation of copper contamination in the healing mud from Makirina Bay, central Adriatic. Environ Int 31(1):53-61

Wei Z, Wu S, Zhou S, Lin C (2013) Installation of impervious surface in urban areas affects microbial biomass, activity (potential $\mathrm{C}$ mineralisation) and function diversity of the fine earth. Soil Res 51:59-67

Wesolek G (2008) Sealing of soils. In: Marzluff JM, Shulenberger E, Endlicher W, Alberti M, Bradley G, Ryan C, Simon U, Zumbunnen C (eds) Urban ecology. Springer Science, Business Media LLC, pp. 161-179

Wong CSC, Li XD, Thornton I (2006) Urban environmental geochemistry of trace metals. Environ Pollut 142:1-16

Xia X, Chen X, Liu R, Liu H (2011) Heavy metals in urban soils with various types of land use in Beijing, China. J Hazard Mater 186: 2043-2051

Zhao D, Feng L, Wang R, Qingrui R (2012) Effect of soil sealing on the microbial biomass, $\mathrm{N}$ transformation and related enzymes activities at various depths of soils in urban area of Beijing, China. J Soils Sediments 12:519-539

Zheng YM, Chen TB, He JZ (2008) Multivariate geostatistical analysis of heavy metals in topsoils from Beijing, China. J Soils Sediments 8: $51-58$ 